\title{
Release of Digestive Enzymes from Isolated Rat Pancreatic Acini Following Muscarinic Stimulation: A Comparative Study with Enzyme Release and Receptor Binding
}

\author{
Masato Kato, Seitaro Ohkuma, Keisho Kataoka ${ }^{1}$, Kei Kashima ${ }^{1}$, \\ Teruo Mukainaka ${ }^{2}$ and Kinya Kuriyama* \\ Department of Pharmacology, 'Third Department of Internal Medicine \\ and ${ }^{2}$ Laboratory of Electron Microscopy, Kyoto Prefectural University of Medicine, \\ Kawaramachi-Hirokoji, Kamikyo-ku, Kyoto 602, Japan
}

Received February 18, 1991 Accepted March 23, 1991

\begin{abstract}
Effect of cholinergic stimulation on the release of digestive enzymes from isolated rat pancreatic acini prepared by collagenase digestion was investigated. The release of enzymes (amylase, chymotrypsinogen, lipase) increased linearly with the time of incubation in the absence of secretagogues. Carbachol, a muscarinic agonist, induced a remarkable increase in the release of these enzymes. This carbacholstimulated amylase release showed a biphasic curve, and its maximal response was observed at $10^{-5} \mathrm{M}$. The release patterns of chymotrypsinogen and lipase were similar to that of amylase. This carbachol-stimulated amylase release was inhibited by atropine in a dose-dependent manner, with an $\mathrm{ED}_{50}$ value of $1.17 \times 10^{-8} \mathrm{M}$. Other cholinergic agonists such as methacholine also stimulated the release of these enzymes, and these increases in the release were inhibited by atropine. Scatchard analysis for $\left[{ }^{3} \mathrm{H}\right]$ quinuclidinyl benzilate $\left(\left[{ }^{3} \mathrm{H}\right] \mathrm{ONB}\right)$ binding to isolated pancreatic acini revealed that the binding site of $\left[{ }^{3} \mathrm{H}\right] \mathrm{QNB}$ was a single component with a $\mathrm{K}_{\mathrm{d}}$ value of $0.09 \mathrm{nM}$ and a $B_{\max }$ value of $89.3 \mathrm{fmol} / \mathrm{mg}$ protein, respectively. The effect of other cholinergic antagonists, pirenzepine and AF-DX 116 (11-[[2-[(diethylamino) methyl]1-piperidinyl]acetyl]-5,11-dihydro-6H-pyrido|2,3-b][1,4]-benzodiazepine-6-one), on pancreatic acini was also investigated. Based on these results, it has been concluded that isolated rat pancreatic acini have muscarinic receptors and are useful for analyzing the mechanism of pancreatic enzyme secretion.
\end{abstract}

Pancreatic exocrine secretion is regulated by neural and humoral factors (1-3). Recent dcvelopment in the techniques to isolate pancreatic acinar cells such as enzyme digestion, chelation and mechanical shearing procedures $(2,4,5)$ have facilitated the pharmacological

\footnotetext{
* To whom correspondence should be addressed.
}

analyses of such regulatory mechanisms on pancreatic exocrine secretion. In fact, pancreatic physiological functions including the responsiveness of enzyme secretion to various secretagogues and receptors coupled with pancreatic exocrine function has been clarified $(6-9)$. Amylase secretion has been used as an index for pancreatic exocrine function and for 
investigating the regulatory roles of receptor activation on the secretion. In spite of the important physiological roles of pancreatic exocrine glands in the secretion of lipase and chymotrypsinogen as well as amylase, few reports dealing with the mechanisms of in vitro secretion of these enzymes are available (10, 11). Therefore in the present study, we have attempted to examine the functional coupling between muscarinic receptors and enzyme release using isolated rat pancreatic acini prepared by enzyme digestion.

\section{MATERIALS AND METHODS}

\section{Materials}

Soybean trypsin inhibitor (type 1-S) and HEPES (N-2-hydroxy-ethyl-piperadine-N'-2ethanesulfonic acid) were purchased from Sigma Chemical Co. (St. Louis, U.S.A.). Collagenase (type 4) and minimal Eagle's medium amino acid supplement were obtained from Worthington Biochemicals (Freehold, U.S.A.) and Gibco (Grand Island, U.S.A.), respectively. Miles Laboratories (Elkhart, U.S.A.) was the source of bovine serum albumin (fraction 5 , powder). $\left[{ }^{3} \mathrm{H}\right]$ Quinuclidinyl benzilate $\left(\left[{ }^{3} \mathrm{H}\right] \mathrm{ONB}, \quad 42.6 \mathrm{Ci} / \mathrm{mmol}\right)$ was purchased from New England Nuclear (Boston, U.S.A.). AF-DX 116 was a kind gift from Boehringer Ingelheim (Elmsford, U.S.A.). Other chemicals used were locally available and of analytical grade.

\section{Preparation of pancreatic acini}

Male Wistar rats weighing $200 \mathrm{~g}$ to $300 \mathrm{~g}$ having free access to laboratory chow and water ad libitum were used for the preparation of pancreatic acini. Pancreatic acini were prepared according to the procedure described previously $(6,12)$ with a minor modification. Krebs-Henseleit-bicarbonate buffer (KHB) $(110 \mathrm{mM} \mathrm{NaCl}, 32.5 \mathrm{mM} \mathrm{NaHCO}, 4.7 \mathrm{mM}$ $\mathrm{KCl}, 1.13 \mathrm{mM} \mathrm{MgCl}, 1 \mathrm{mM} \mathrm{Na} \mathrm{HPO}_{4}, 2 \mathrm{mM}$ glutamine and $11.1 \mathrm{mM}$ glucose) containing $0.01 \%$ trypsin inhibitor and minimal Eagle's medium amino acid supplement was used as the basic medium. The medium used for preincubation and reaction of enzyme release was HEPES-buffered Ringer solution (HR) containing $127 \mathrm{mM} \mathrm{NaCl}, 4.7 \mathrm{mM} \mathrm{KCl}, 1.2$ $\mathrm{mM} \mathrm{CaCl}, 0.56 \mathrm{mM} \mathrm{MgCl}, 1 \mathrm{mM} \mathrm{Na} 2 \mathrm{HPO}_{4}$, $10 \mathrm{mM}$ HEPES, $2 \mathrm{mM}$ glutamine, $11.1 \mathrm{mM}$ glucose, $0.01 \%$ trypsin inhibitor, minimal Eagle's medium amino acid supplement and $0.5 \%$ bovine serum albumin. All media used in this study were adequately gassed with $95 \%$ $\mathrm{O}_{2}-5 \% \mathrm{CO}_{2}$ and $\mathrm{pH}$ adjusted to 7.4 .

Rats were sacrificed, and the pancreas was immediately removed and trimmed of fat and mesentery. Five milliliters of the basic medium containing collagenase $(1 \mathrm{mg} / \mathrm{ml})$ and $0.1 \mathrm{mM}$ $\mathrm{CaCl}_{2}$ (the medium for dissociation) was injected into the pancreas to make it swell. This swollen pancreas was then minced and incubated in a $25 \mathrm{ml}$ Erlenmyer flask with reciprocal shaking ( 120 strokes $/ \mathrm{min}$ ) at $37^{\circ} \mathrm{C}$ for 10 min. After this first incubation, excess medium was discarded, and $5 \mathrm{ml}$ of fresh dissociation medium was added. The pancreas was incubated again under the above-described conditions for $40 \mathrm{~min}$. The digested pancreas was then mechanically disrupted by aspirating up and down through pipettes with decreasing orifice size. After the disrupted pancreatic tissue was filtered through a nylon sieve (mesh size $0.15 \mathrm{~mm}$ ), the sieve was rinsed with $10 \mathrm{ml}$ of the basic medium containing $1 \% \mathrm{BSA}$ and $0.1 \mathrm{mM} \mathrm{CaCl}$. The filtrate containing pancreatic acini was then centrifuged $\left(50 \times g, 4^{\circ} \mathrm{C}, 4 \mathrm{~min}\right)$ and the pellet thus obtained was resuspended with the basic medium containing $4 \%$ BSA and $0.5 \mathrm{mM}$ $\mathrm{CaCl}_{2}$ and centrifuged $\left(50 \times g, 4^{\circ} \mathrm{C}, 4 \mathrm{~min}\right)$. Finally, pancreatic acini were suspended with HR and preincubated for $30 \mathrm{~min}$ before each experimental use.

\section{Morphological observation}

The morphological features of the isolated pancreatic acini were examined by phase contrast microscopy and transmission electron microscopy. Phase contrast micrographical studies were directly carried out under a phase contrast microscope (Nikon Diaphoto-TMD). For transmission electron microscopical ex- 
aminations, isolated acini were prefixed with $0.1 \mathrm{M} \mathrm{KRB}$ buffer containing $2.5 \%$ glutaraldehyde, followed by the fixation with $1 \%$ $\mathrm{OsO}_{4}$. The fixed acini were dehydrated with ethanol, inversed in propylene dioxide, and finally embedded in Epon. The ultrathin sections were stained with uranyl acetate and poststained with lead nitrate and then examined by a Hitachi HS-11 electron microscope.

\section{Measurement of viability of pancreatic acini}

To evaluate the viability of pancreatic acinar cells, the trypan blue exclusion test and measurement of the leakage of lactic dehydrogenase (LDH) activity were employed. Trypan blue dye dissolved in $0.9 \% \mathrm{NaCl}$ solution was added to the suspension of pancreatic acini to a final concentration of $0.2 \%$, and unstained cells were counted under a microscope. LDH activities in cells and medium were assayed by the method of Wroblewski (13). The leaked LDH activity was expressed as a percentage of the total initial content in cells.

\section{Determination of enzyme secretion}

After the preincubation with reciprocal shaking $(60 \mathrm{strokes} / \mathrm{min})$ at $37^{\circ} \mathrm{C}$ for $30 \mathrm{~min}$, acini were centrifuged and resuspended in fresh HR to adjust the protein concentration of $0.3-0.5 \mathrm{mg}$ protein $/ \mathrm{ml}$. Four milliliters of this suspension was transferred to $25-\mathrm{ml}$ siliconized glass flasks and then incubated with reciprocal shaking (60 strokes $/ \mathrm{min})$ at $37^{\circ} \mathrm{C}$ with various agents. Following incubation of various intervals, $1 \mathrm{ml}$ of cell suspension was centrifuged at $10,000 \times g$ by a Beckman microcentrifuge for $20 \mathrm{sec}$, and the supernatant obtained was subjected to the determination of various digestive enzymes. Enzyme activity determined in the supernatant before incubation was taken as the value at zero time. The net value of secreted enzyme activity obtained after incubation with various drugs was calculated by subtracting the enzyme activity detected in the supernatant before incubation (zero time) from that detected in the supernatant after incubation with drugs. The total activity of each enzyme in the cells before incubation was measured as follows: The pellet obtained at zero time was rinsed with ice-cold $0.9 \% \mathrm{NaCl}$, recentrifuged and the same volume of distilled water was added. This sample was homogenized by a Polytron homogenizer and then subjected for the measurements of both enzyme activity and protein content. The enzyme released into the medium during the incubation was expressed as the percentage of total initial content of enzyme activity in pancreatic acini. Amylase activity was assayed by the method of Ceska et al. (14) using the Phadebas blue starch test. Chymotrypsinogen was initially converted to chymotrypsin by bovine trypsin according to the method of Dagorn (15), and the activity of chymotrypsin was assayed by the method of Imondi with a modification using N-benzoyl-Ltyrosyl-p-aminobenzoic acid (BT-PABA) as a substrate (16). Lipase activity was determined by the BALB-DTNB method (17). Protein was measured by the method of Lowry et al. with bovine serum albumin as a standard (18).

\section{Muscarinic receptor binding assay}

Muscarinic receptor binding was carried out according to the methods described previously with a minor modification $(19,20)$ using $\left[{ }^{3} \mathrm{H}\right]$ quinuclidinyl benzilate $\left(\left[{ }^{3} \mathrm{H}\right] \mathrm{QNB}, 42.6\right.$ $\mathrm{Ci} / \mathrm{mmol}$ ) as a radiolabeled ligand for the muscarinic receptor. After the preincubation of acini at $37^{\circ} \mathrm{C}$ for $30 \mathrm{~min}$, acini $(0.05-0.18$ $\mathrm{mg}$ protein $/ \mathrm{ml}$ of suspension) in HR without bovine serum albumin were incubated with various concentrations of $\left[{ }^{3} \mathrm{H}\right] \mathrm{QNB}$ at $37^{\circ} \mathrm{C}$ for $180 \mathrm{~min}$. The total volume used for the receptor binding assay was $4 \mathrm{ml}$. Specific binding was calculated by subtracting the binding obtained in the presence of $10^{-5} \mathrm{M}$ atropine from the total binding determined in the $a b$ sence of atropine. Each binding assay was performed in triplicate. The reaction was terminated by filtering the cell suspension through a Whatman GF/B filter under vacuum, followed by three times washing with icc-cold $0.9 \% \mathrm{NaCl}$ solution (total volume: 15 $\mathrm{ml}$ ). The filter was transferred to a scintilla- 
tion vial containing $10 \mathrm{ml}$ scintillation cocktail, and the radioactivity was measured by a liquid scintillation spectrometer.

\section{Statistics}

All results obtained were expressed as the mean \pm S.E., and Student's $t$-test was employed to determine statistical significance.

\section{RESULTS}

\section{Morphological features of isolated pancreatic acini}

Figure 1-A shows a phase microscopic view of the isolated acini. The preparation consisted of single cells and clumps of cells with acinar configuration. No contamination of duct fragments and islets of Langerhans was observed. The transmission electron micrograph of isolated acini revealed that intracellular organellae such as nuclei, mitochondrias, zymogen granules, endoplasmic reticulums and ribosomes appeared to retain their normal structure (Fig. 1-B). The zymogen granules in each cell were localized at the apical site of cells rather than the site opposite to the lumen. These morphological observations clearly demonstrate that the isolated pancreatic acini used in this study possess morphological features typical to pancreatic acinar cells.

\section{Viability of acinar cells}

Two types of tests were employed to evaluate the viability of pancreatic acini, namely the activity to exclude trypan blue dye and the leakage of lactic dehydrogenase (LDH) activity from isolated acini into the incubation medium. Figure 2 shows the changes in the viability of isolated acini during incubation in $\mathrm{KHB}$ buffer at $37^{\circ} \mathrm{C}$. Immediatcly after the isolation, only less than $10 \%$ of the acini was stained by trypan blue dye. Although the proportion of isolated acini excluding trypan blue dye showed a gradual decrease during the examined incubation period, it was found that more than $80 \%$ of the isolated acini showed the activity to exclude dye even after $180 \mathrm{~min}$ of incubation (Fig. 2-A). Leakage of $\mathrm{LDH}$ activity from isolated acini into the incubation medium increased gradually with the time of incubation. However, the leakage of LDH activity was less than $5 \%$ of the total $\mathrm{LDH}$ activity at 3 hours after the initiation of incubation (Fig. 2-B). Based on these results, it is likely that the isolated acini used in the present study retain good viability.

\section{Characteristics of enzyme release from isolated pancreatic acini by secretagogues}

The time course of amylase release from isolated pancreatic acini in the presence or absence of carbachol $\left(10^{-6} \mathrm{M}\right)$ is shown in Fig. 3. The increase in amylase release in the absence of carbachol exhibited a linearity with time of incubation. On the other hand, amylase release in the presence of carbachol $\left(10^{-6}\right.$ M) showed a remarkable increase during the first $30 \mathrm{~min}$ of incubation, and the rate of increase was found to be linear until $120 \mathrm{~min}$ of incubation. When the carbachol-stimulated secretion of amylase was expressed as the ratio to the value determined in the absence of carbachol, the ratio exhibited its maximum value (about 4 fold of the value without carbachol) at $30 \mathrm{~min}$ after the initiation of incubation (Fig. 3). According to these results, amylase release induced by secretagogues was determined during the first $30 \mathrm{~min}$ after the addition of secretagogues.

Based on the data that the releases of chymotrypsinogen and lipase from pancreatic acini by carbachol $\left(10^{-5} \mathrm{M}\right)$ became linear 60 and $30 \mathrm{~min}$ after the addition of carbachol, respectively, the incubation time for examining the releases of chymotrypsinogen and lipase in the presence of secretagogues was determined at 60 and $30 \mathrm{~min}$ after the addition of carbachol, respectively.

Figure 4-A shows the dose-response curve for amylase release stimulated by various concentrations of carbachol. This curve was bellshaped and the maximal response was observed at $10^{-5} \mathrm{M}$. To examine whether or not the stimulatory effect of carbachol on amylase release from isolated pancreatic acini was mediated by muscarinic receptors, the 

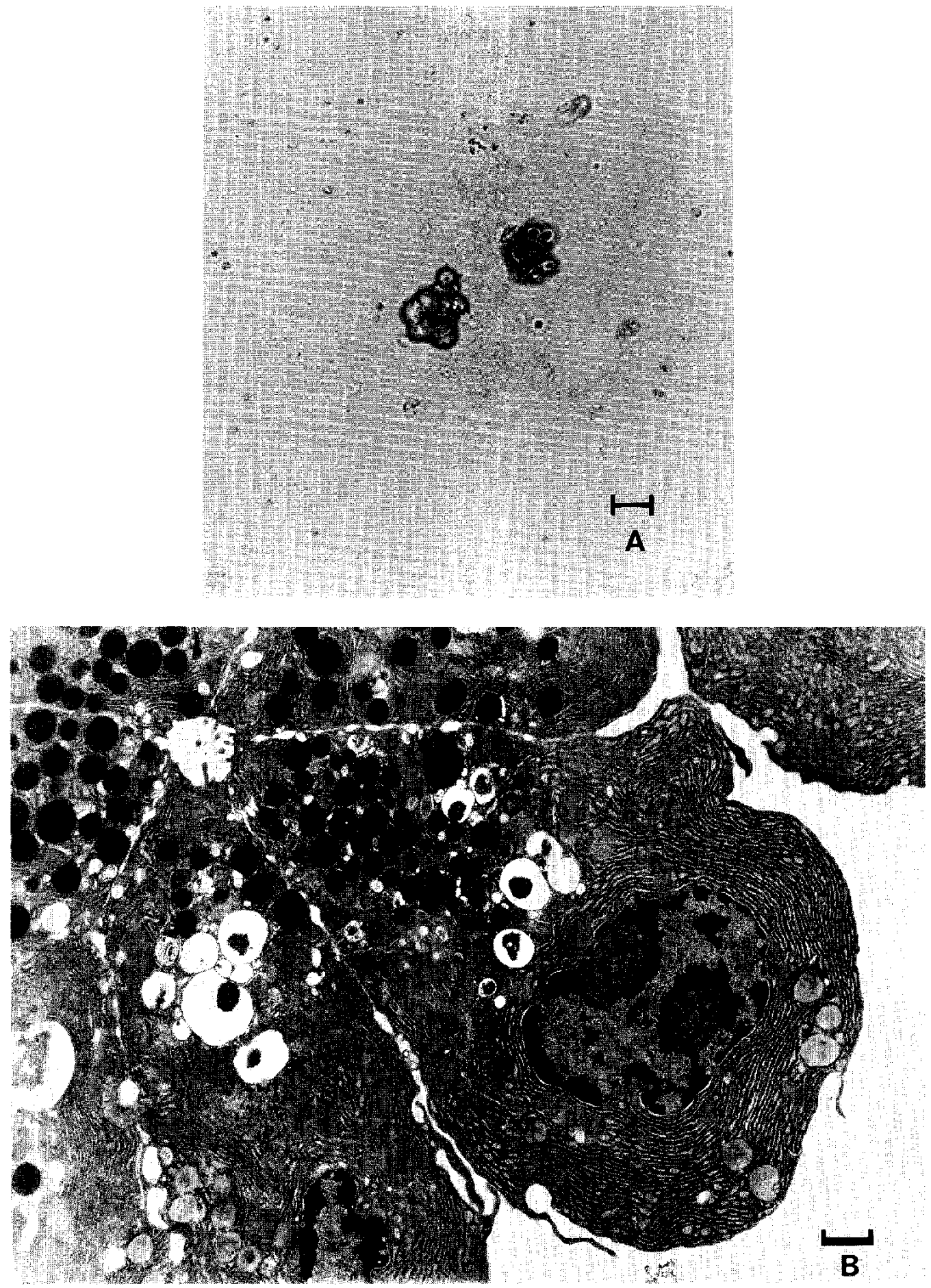

Fig. 1. Phase contrast micrograph (A) and transmission electron micrograph (B) of isolated acini from rat pancreas. Scale bar: $0.1 \mathrm{~mm}(\mathrm{~A}), 1 \mu \mathrm{m}(\mathrm{B})$. 
Trypan Blue Exclusion

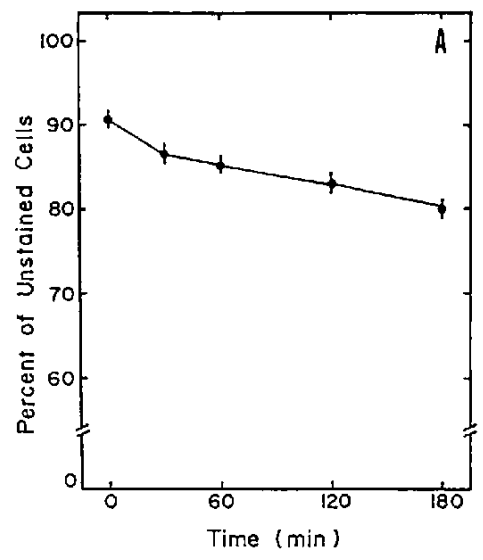

Leakage of Loctic Dehydrogenase (LDH)

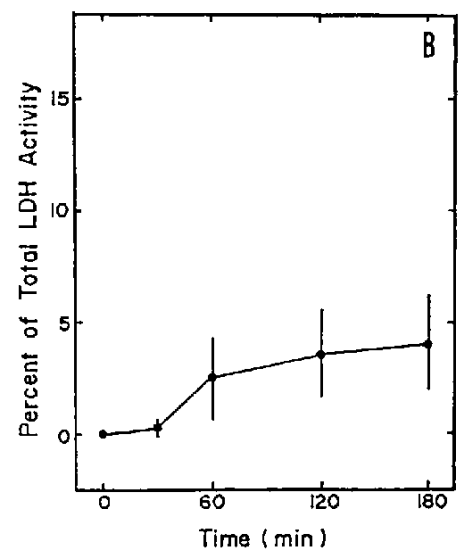

Fig. 2. Changes in viability of isolated rat pancreatic acini during incubation. Each value represents the mean \pm S.E. of 4 separate experiments. A) Trypan blue exclusion test. B) Leakage of lactic dehydrogenase (LDH).

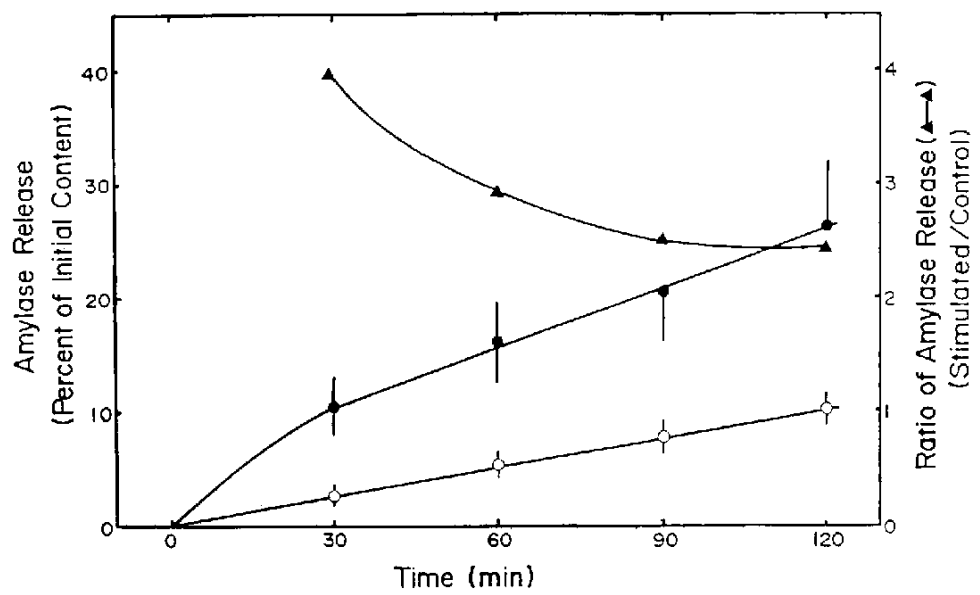

Fig. 3. Time course of amylase release from isolated pancreatic acini. Acini werc incubated with (closed circle) or without (open circle) $10^{-6} \mathrm{M}$ carbachol in HEPES Ringer buffer at $37^{\circ} \mathrm{C}$. Triangle: The ratio of stimulated amylase release to unstimulated release. Each value represents the mean $\pm S$.E. of 4 separate experiments.

effect of atropine on the carbachol-stimulated amylase release was investigated. Atropine inhibited the carbachol-stimulated amylase release in a dose-dependent manner as shown in Fig. 5, and the $E D_{50}$ value for atropine was $1.17 \times 10^{-8} \mathrm{M}$. In addition, other muscarinic agonists such as methacholine and acetylcholine also induced a significant increase of amylase release at the concentration of $10^{-6} \mathrm{M}$. Furthermore, the increase in amylase release induced by these drugs was significantly inhibited by $10^{-5} \mathrm{M}$ atropine (Table 1 ).

The effects of methacholine and bethanechol, muscarinic agonists, on the releases of chymotrypsinogen and lipase were also examined. The release of both enzymes from 

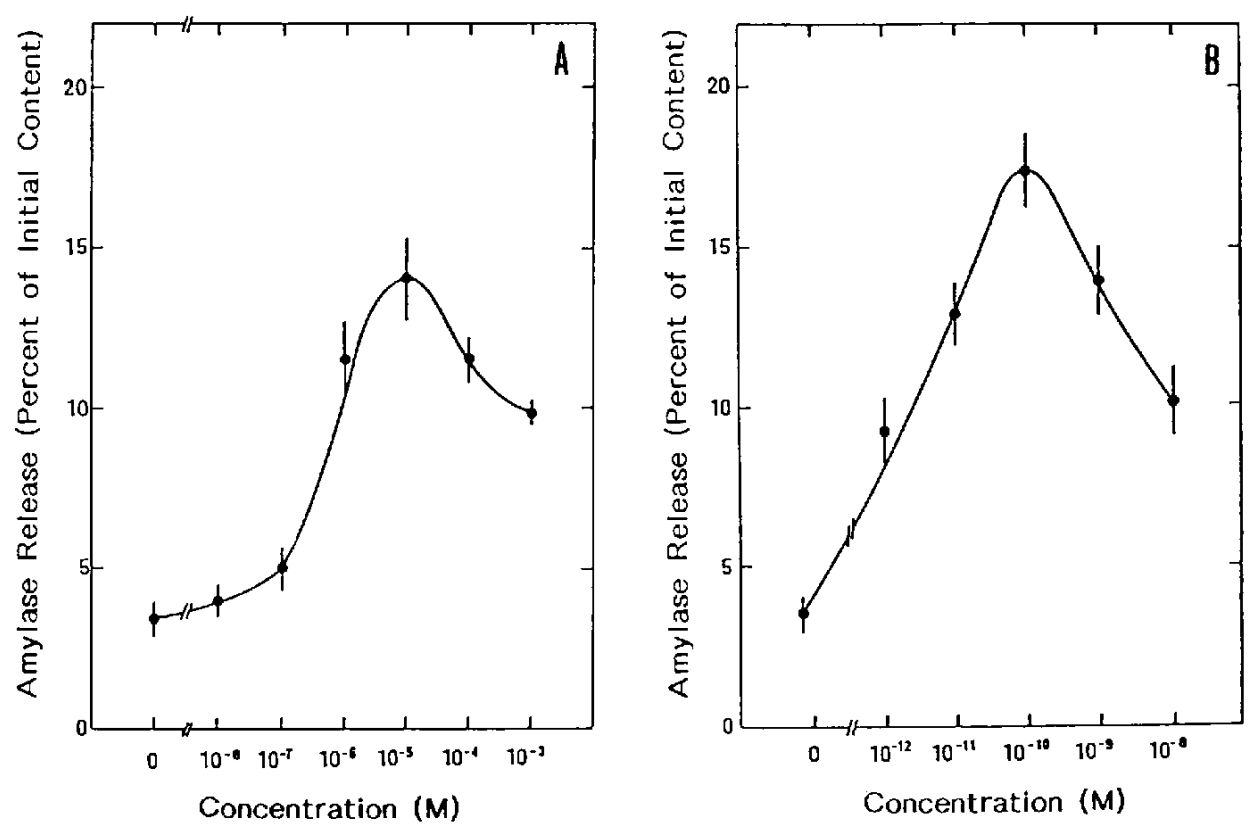

Fig. 4. Amylase release from isolated pancreatic acini in the presence of carbachol and CCK-8. Amylase release during incubation $\left(30 \mathrm{~min}, 37^{\circ} \mathrm{C}\right)$ was expressed as a percentage of the total initial content. Each value represents the mean \pm S.E. of 6 separate experiments. A) Amylase release in the presence of various concentrations of carbachol. B) Amylase release in the presence of various concentrations of CCK- 8 .

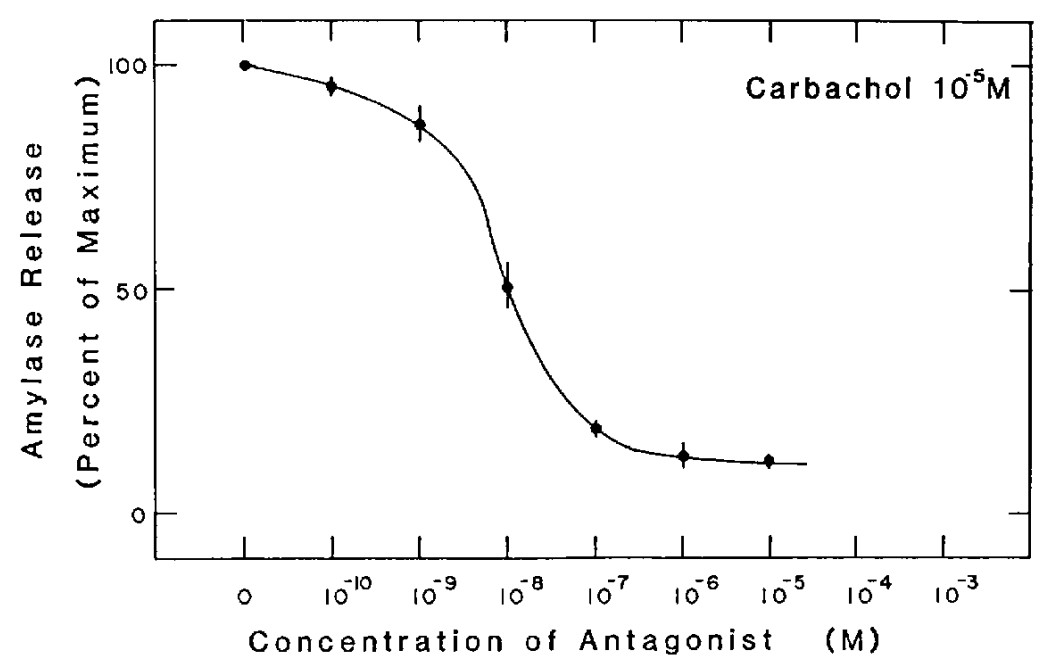

Fig. 5. Effect of atropine on carbachol-stimulated amylase release from isolated rat pancreatic acini. Pancreatic acini were incubated for $30 \mathrm{~min}$ at $37^{\circ} \mathrm{C}$ with $10^{-5} \mathrm{M}$ carbachol and various concentrations of atropine. Each value represents the mean \pm S.E. of 4 separate experiments. 
Table 1. Effects of muscarinic agonists and atropine on amylase release from isolated rat pancreatic acini

\begin{tabular}{llcc}
\hline & & \multicolumn{2}{c}{ Amylase release (percent of control) } \\
\cline { 3 - 4 } Drug & & Atropine $(-)$ & Atropine $(+)^{\text {a) }}$ \\
\hline Carbachol & $10^{-5} \mathrm{M}$ & $493.1 \pm 55.0$ & $88.5 \pm 9.1$ \\
Methacholine & $10^{-6} \mathrm{M}$ & $458.0 \pm 35.2$ & $95.4 \pm 5.8$ \\
Acetylcholine & $10^{-6} \mathrm{M}$ & $401.5 \pm 27.2$ & $92.1 \pm 7.1$ \\
\hline
\end{tabular}

Pancreatic acini were incubated for $30 \mathrm{~min}$ at $37^{\circ} \mathrm{C}$ with various drugs. The concentration of atropine was $10^{-5} \mathrm{M}$. Each value is expressed as a percentage of the amylase release without any drugs. Each value represents the mean \pm S.D. of 4 to 6 separate experiments. ${ }^{\text {) }}$ Atropine $10^{-5} \mathrm{M}$.

Table 2. Effects of muscarinic agonists and atropinc on releases of chymotrypsinogen and lipase from isolated rat pancreatic acini

\begin{tabular}{|c|c|c|c|c|c|}
\hline \multirow{2}{*}{ Drug } & & \multicolumn{2}{|c|}{$\begin{array}{l}\text { Chymotrypsinogen release } \\
\text { (percent of control) }\end{array}$} & \multicolumn{2}{|c|}{ Lipase release (percent of control) } \\
\hline & & Atropine $(-)$ & Atropine $(+)^{a)}$ & Atropine $(-)$ & Atropine $(t)^{a}$ \\
\hline Carbachol & $10^{-5} \mathrm{M}$ & $359.4 \pm 21.8$ & $101.5 \pm 4.6$ & $381.7 \pm 42.0$ & $103.5 \pm 15.1$ \\
\hline Methacholine & $10^{-6} \mathrm{M}$ & $339.6 \pm 6.1$ & $98.6 \pm 1.0$ & $360.9 \pm 46.3$ & $99.6 \pm 2.3$ \\
\hline Bethanechol & $10^{-6} \mathrm{M}$ & $129.6 \pm 2.6$ & $100.8 \pm 3.7$ & $176.6 \pm 38.5$ & $100.4 \pm 8.7$ \\
\hline
\end{tabular}

Pancreatic acini were incubated for $60 \mathrm{~min}$ and $30 \mathrm{~min}$ at $37^{\circ} \mathrm{C}$ to measure the releases of chymotrypsinogen and lipase, respectively. The concentration of atropine was $10^{-5} \mathrm{M}$. Each value is expressed as a percentage of the amylase release without any drugs. Each value represents the mean \pm S.D. of 4 to 6 separate experiments. a) Atropine $10^{-5} \mathrm{M}$.

isolated acini were significantly stimulated by muscarinic agonists at the concentration of $10^{-6} \mathrm{M}$ (Figs. 6 and 7 ). In addition, the increase of the release of these enzymes was also found to be significantly inhibited by $10^{-5} \mathrm{M}$ atropine (Table 2).

Cholecystokinin (CCK) is also known as one of the secretagogues that induces the release of amylase from the pancreas. Therefore in this study, we have examined the effect of CCK on the releases of chymotrypsinogen and lipase from isolated pancreatic acini. Figure 4$\mathrm{B}$ shows the dose-response curve for amylase release in the presence of CCK-octapeptide (CCK-8), a peptide thought to bind to a receptor different from the muscarinic receptor. CCK-8 $\left(10^{-10} \mathrm{M}\right)$ induced a maximal response, and the dose response curve showed a similar shape to that observed in the presence of carbachol. Similar dose-responses of CCK-8 were obtained in the releases of chymotrypsinogen and lipase.

Effect of antagonists for muscarinic receptor subtypes on carbachol-stimulated amylase release from isolated pancreatic acini

Effect of pirenzepine $(\mathrm{PZ})$, a $\mathrm{M}_{1}$ receptor antagonist, and AF-DX 116, a cardio-selective $\mathrm{M}_{2}$ receptor antagonist, on the carbacholstimulated amylase release was also investigated. These antagonists exhibited a dose-dependent inhibition on the carbachol-stimulated amylase release (Fig. 8), and the $\mathrm{ED}_{50}$ values of PZ and AF-DX 116 were found to be 4.39 $\times 10^{-6} \mathrm{M}$ and $5.06 \times 10^{-5} \mathrm{M}$, respectively. 

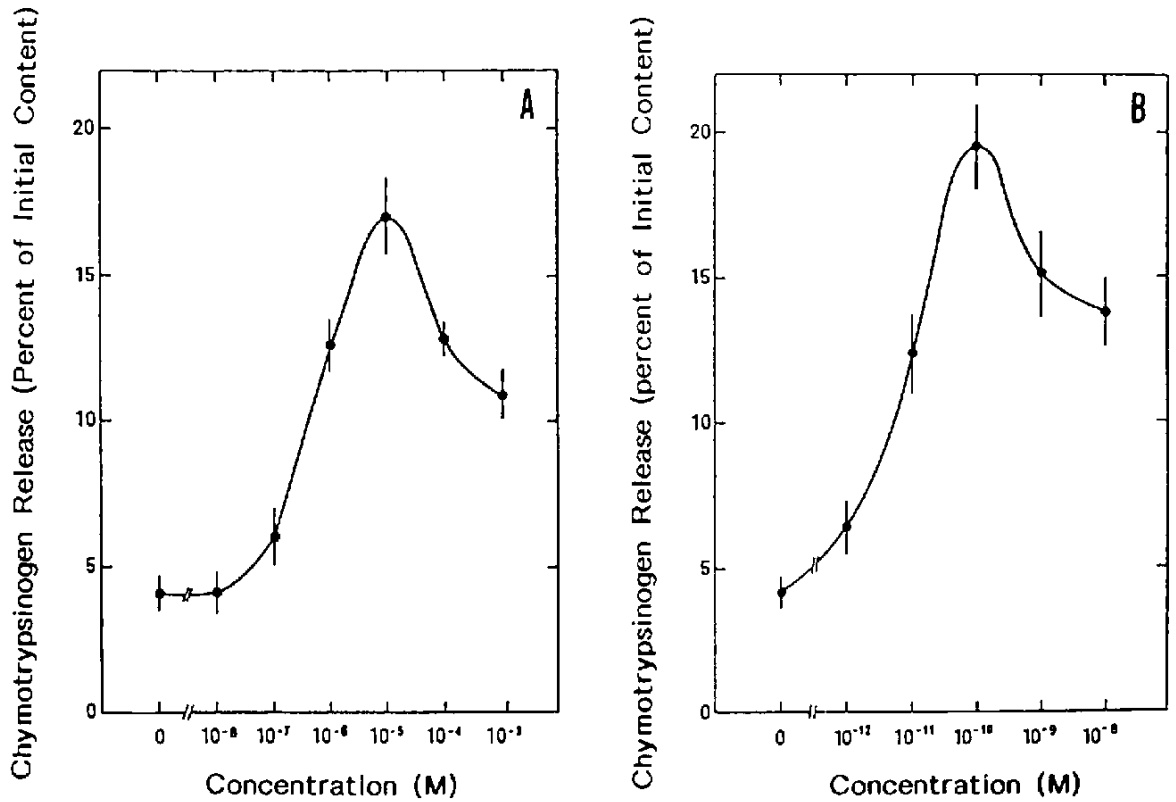

Fig. 6. Chymotrypsinogen release from isolated pancreatic acini in the presence of carbachol and CCK-8. Chymotrypsinogen release during incubation $\left(60 \mathrm{~min}, 37^{\circ} \mathrm{C}\right.$ ) was expressed as a percentage of the total initial content. Each value represents the mean $\pm \mathrm{S}$.E. of 4 separate experiments. A) Chymotrypsinogen release in the presence of various concentrations of carbachol. B) Chymotrypsinogen release in the presence of various concentrations of CCK-8.
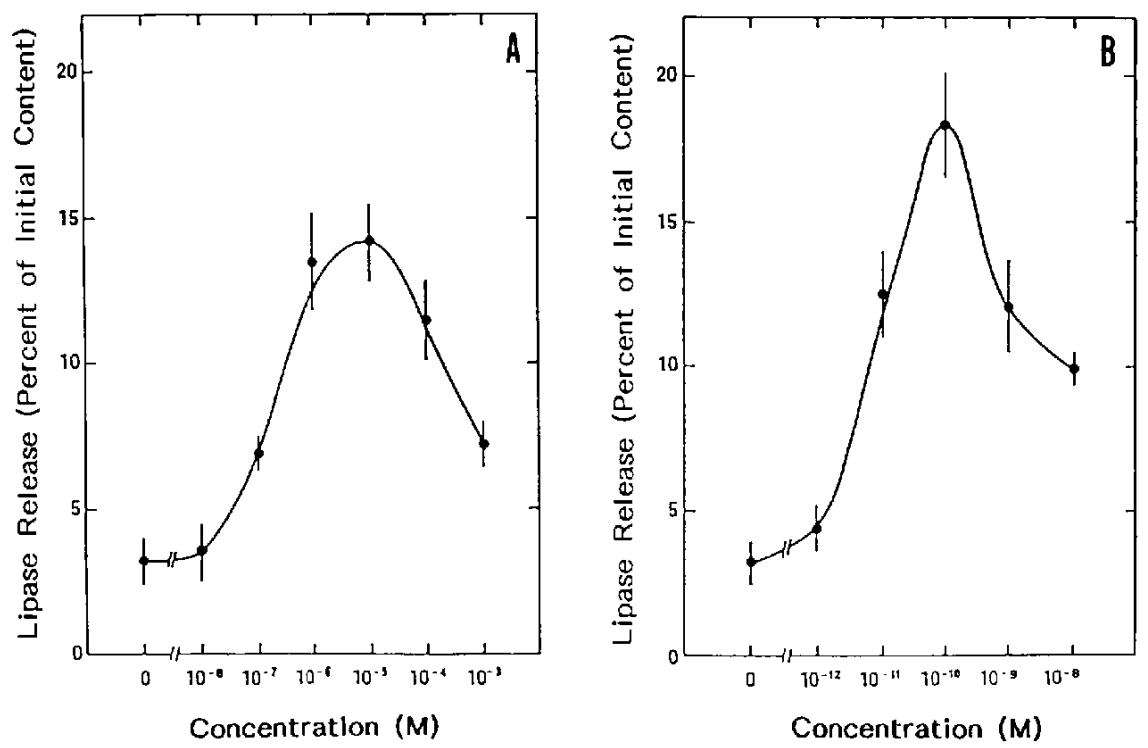

Fig. 7. Lipase release from isolated pancreatic acini in the presence of carbachol and CCK-8. Lipase release during incubation $\left(30 \mathrm{~min}, 37^{\circ} \mathrm{C}\right.$ ) was expressed as a percentage of the total initial content. Each value represents the mean \pm S.E. of 4 separate experiments. A) Lipase release in the presence of various concentrations of carbachol. B) Lipase release in the presence of various concentrations of CCK-8. 


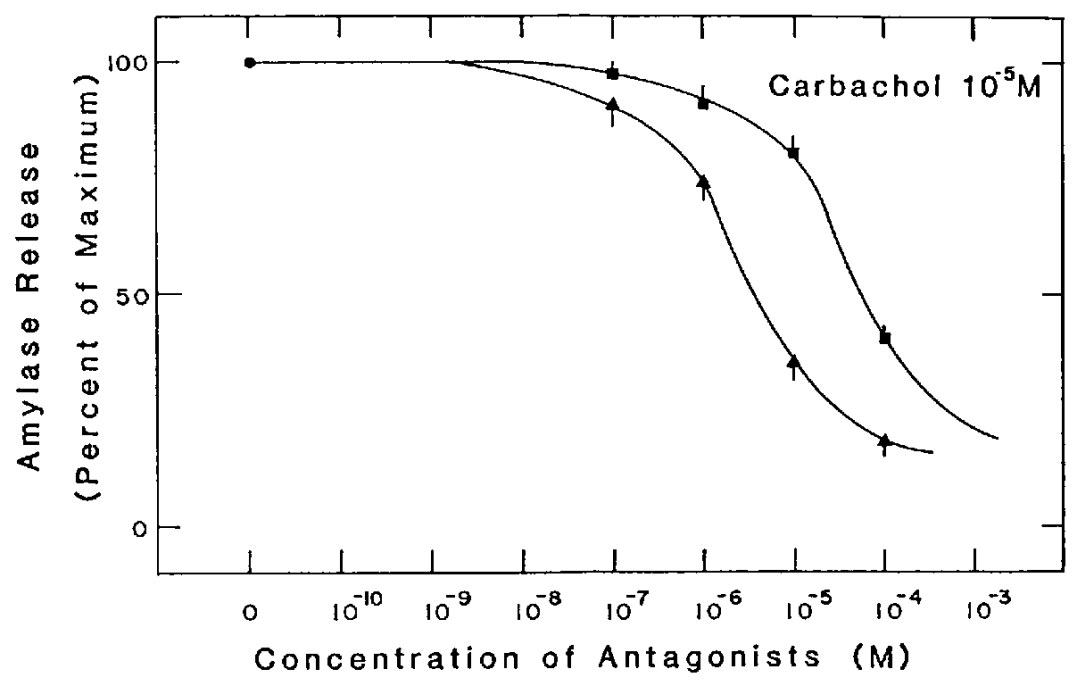

Fig. 8. Effects of pirenzepine (PZ, $\Delta$ ) and AF-DX $116(\square)$ on carbachol-stimulated amylase release from isolated rat pancreatic acini. Pancreatic acini were incubated for $30 \mathrm{~min}$ at $37^{\circ} \mathrm{C}$ with $10^{-5} \mathrm{M}$ carbachol and varying concentrations of $\mathrm{PZ}$ and AF-DX 116. Each value represents the mean $\pm \mathrm{S}$.E. of 4 separate experiments.

Characteristics of muscarinic receptors of isolated pancreatic acini

Pharmacological characteristics of muscarinic receptors of isolated pancreatic acini were examined using $\left[{ }^{3} \mathrm{H}\right]$ quinuclidinyl benzilate $(\mathrm{QNB})$ as a radiolabeled ligand. The amount of $\left[{ }^{3} \mathrm{H}\right] \mathrm{QNB}$ specifically bound to pancreatic acini showed a relatively slow increase with the time of incubation and reached a plateau at about $150 \mathrm{~min}$ after the addition of $\left[{ }^{3} \mathrm{H}\right] \mathrm{QNB}$ into the incubation medium (data not shown). For measuring the specific binding of $\left[{ }^{3} \mathrm{H}\right] \mathrm{QNB}$ to pancreatic acini as a function of $\left[{ }^{3} \mathrm{H}\right] \mathrm{QNB}$ concentration in the incubation medium, pancreatic acini were incubated in the presence of various concentrations of $\left[{ }^{3} \mathrm{H}\right] \mathrm{QNB}(10-2000 \mathrm{pM})$ at $37^{\circ} \mathrm{C}$ for $180 \mathrm{~min}$. The specific $\left[{ }^{3} \mathrm{H}\right] \mathrm{QNB}$ binding was found to be saturable with the increase of $\left[{ }^{3} \mathrm{H}\right] \mathrm{QNB}$ concentration (Fig. 9). Scatchard analysis revealed that isolated pancreatic acini used in this study possessed a high affinity binding site with a $K_{d}$ value of $0.09 \mathrm{nM}$ and a $B_{\max }$ value of $89.3 \mathrm{fmol} / \mathrm{mg}$ protein (Fig. 10). Moreover, this $\left[{ }^{3} \mathrm{H}\right] \mathrm{QNB}$ binding to isolated pancreatic acini was dose-dependently inhibited by atro-

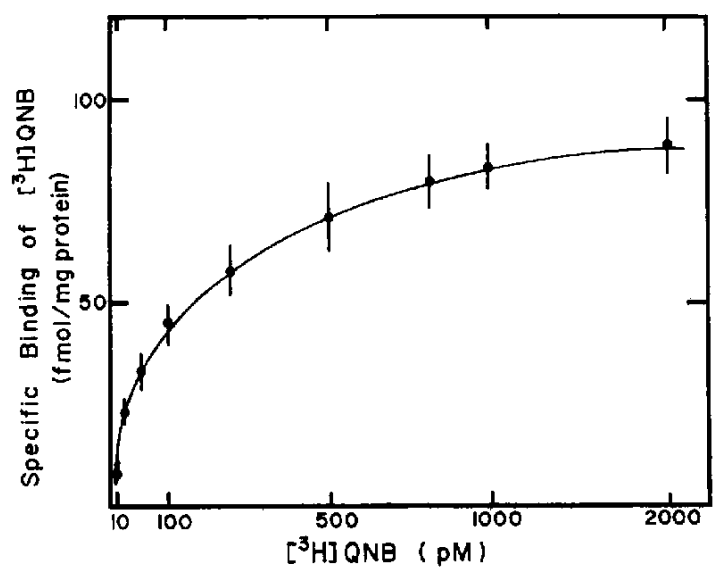

Fig. 9. Specific binding of $\left[{ }^{3} \mathrm{H}\right] \mathrm{QNB}$ to isolated pancreatic acini. Pancreatic acini were incubated in HEPES Ringer buffer for $180 \mathrm{~min}$ at $37^{\circ} \mathrm{C}$ with the indicated concentrations of $\left[{ }^{3} \mathrm{H}\right] \mathrm{ONB}$ in the presence or absence of $10^{-5} \mathrm{M}$ atropine. Each value for specific binding was obtained by subtracting non-specific binding from the total binding. Each values represents the mean \pm S.E. of 4 separate experiments. 
pine with an $\mathrm{IC}_{50}$ value of $2.56 \times 10^{-9} \mathrm{M} \quad\left[{ }^{3} \mathrm{H}\right] \mathrm{QNB}$ binding similar to that of atropine, (Fig. 11). Similarly, the effects of PZ and AF- although the $I_{50}$ values of $P Z$ and AF-DX DX 116 on the $\left[{ }^{3} \mathrm{H}\right] \mathrm{QNB}$ binding was ex- 116 were $2.90 \times 10^{-7} \mathrm{M}$ and $1.21 \times 10^{-6} \mathrm{M}$, amined. These antagonists for muscarinic subtypes also showed an inhibitory effect on respectively (Fig. 12).

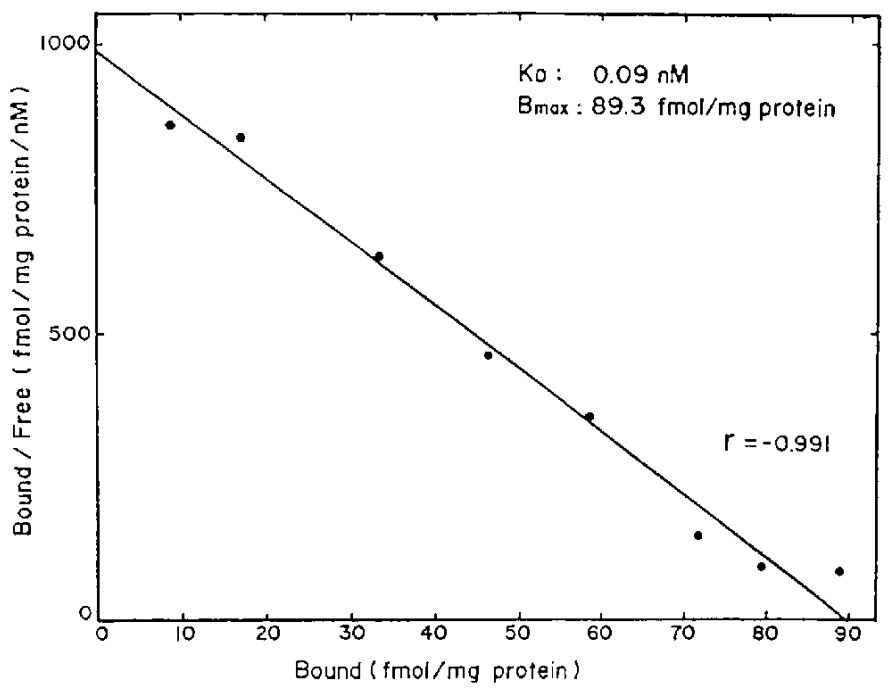

Fig. 10. Scatchard plot of $\left[{ }^{3} \mathrm{H}\right] \mathrm{QNB}$ binding to isolated rat pancreatic acini. Pancreatic acini were incubated in HEPES Ringer buffer for $180 \mathrm{~min}$ at $37^{\circ} \mathrm{C}$ with various concentrations of $\left[{ }^{3} \mathrm{H}\right] \mathrm{QNB}$. Each value represents the mean \pm S.E. of 4 separate experiments.

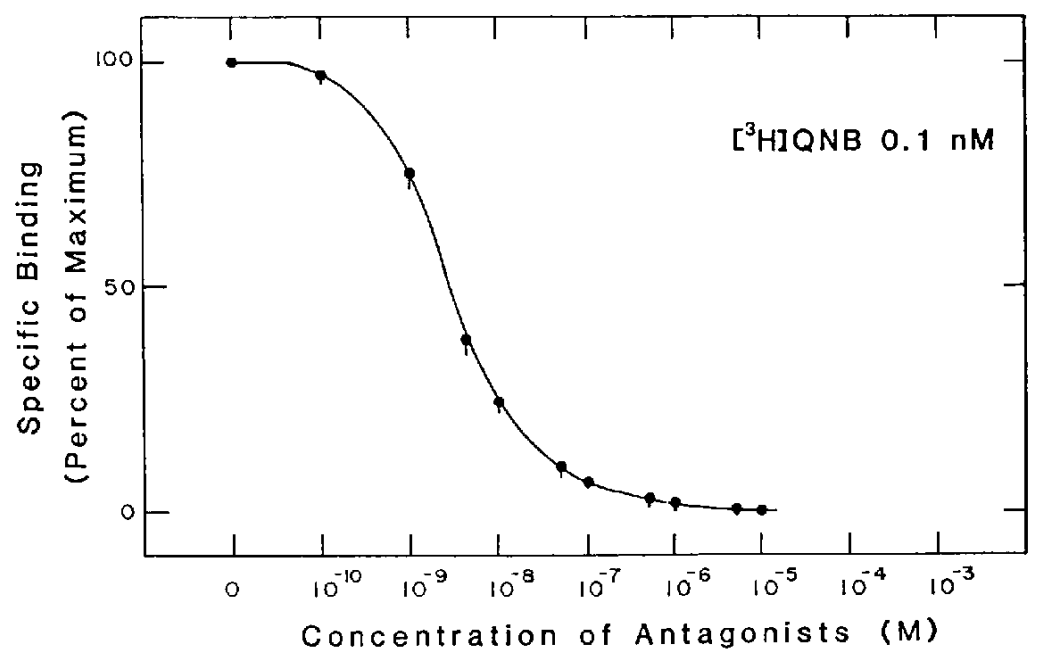

Fig. 11. Effect of atropine on $\left.\left.\right|^{3} \mathrm{H}\right] \mathrm{QNB}$ binding to isolated rat pancreatic acini. Pancreatic acini were incubated in HEPES Ringer buffer for $180 \mathrm{~min}$ at $37^{\circ} \mathrm{C}$ with $0.1 \mathrm{nM}$ of $\left[{ }^{3} \mathrm{H} \mid \mathrm{QNB}\right.$ in the presence of various concentrations of atropine and $0.1 \mathrm{nM}$ of $\left[{ }^{3} \mathrm{H}\right] \mathrm{QNB}$. Values are given as the mean \pm S.E. of 4 separate experiments. 


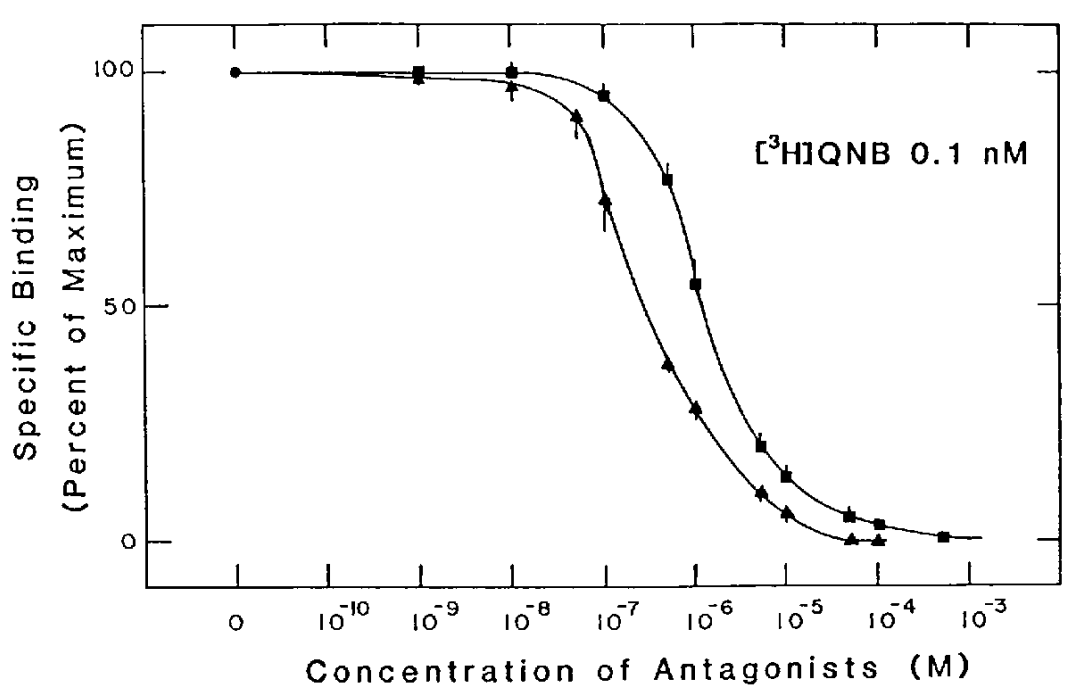

Fig. 12. Effects of pirenzepine (PZ, $\mathbf{A})$ and AF-DX $116(\boldsymbol{\square})$ on $\left[{ }^{3} \mathrm{H}\right] \mathrm{QNB}$ binding to isolated rat pancreatic acini. Pancreatic acini were incubated in HEPES Ringer buffer for $180 \mathrm{~min}$ at $37^{\circ} \mathrm{C}$ with $0.1 \mathrm{nM}$ of $\left[{ }^{3} \mathrm{H}\right] \mathrm{QNB}$ in the presence of various concentrations of PZ and AF-DX 116. Each value represents the mean $\pm \mathrm{S}$.E. of 4 separate experiments.

\section{DISCUSSION}

In the present study, we have examined the morphological characteristics, the enzyme releases in response to muscarinic cholinergic agents and pharmacological characteristics of muscarinic receptors in rat pancreatic acini isolated by collagenase digestion. Morphological studies using transmission electron microscope demonstrated that isolated pancreatic acini retain intact microscopic features, which were in accordance with previously reported data using isolated pancreatic acini and pancreas in vivo $(4,6,21,22)$. In addition, the acini maintained a good viability as judged by the trypan blue exclusion test and the leakage of LDH activity. Therefore, it has been concluded that these isolated pancreatic acini are useful for investigating its physiological functions including the effect of muscarinic stimulation on digestive enzyme release and the characteristics of the muscarinic receptors of the pancreatic acini.

The ratio of carbachol-stimulated amylase release to non-stimulated (basal) amylase release was found to be about 4.0 at $30 \mathrm{~min}$ af- ter the addition of muscarinic agonists, which is in good agreement with the previously reported data $(6,23)$. In this study, the responsiveness of enzymes release (amylasc, chymotrypsinogen, and lipase) to carbachol in isolated pancreatic acini showed a biphasic pattern. It is not clear why such a biphasic pattern of carbachol-stimulated enzymes release was observed in isolated acini. Williams et al. proposed that this phenomenon might be due to a rapid decline in the rate of amylase release following an initial few minutes of stimulation (24) and termed it "desensitization" or "tolerance" (6). On the other hand, Barlas et al. proposed the concept of "restricted stimulation" for the similar phenomenon observed in their experiments, in which amylase release induced by CCK -8 decreased with the highest concentration of CCK-8 (25). It was noteworthy that the patterns of the releases of chymotrypsinogen and lipase in response to CCK8 were similar to that of amylase in the present study. Two hypotheses about pancreatic exocrine secretion, parallel secretion and nonparallel secretion, have been proposed (26, 27). However, from the results demonstrated 
in this study, it has been suggested that pancreatic exocrine cells have the ability to secrete digestive enzymes such as amylase, chymotrypsinogen and lipase in a similar fashion to the secretion of enzymes induced by the stimulation by agonists for muscarinic and CCK receptors.

The present study and other reports have clarified that muscarinic receptors are indeed present on rat pancreatic acini $(19,20)$. The association of $\left[{ }^{3} \mathrm{H}\right] \mathrm{QNB}$ with muscarinic receptors of pancreatic acini was slow, and more than $150 \mathrm{~min}$ was required to attain saturation. On the other hand, $\left[{ }^{3} \mathrm{H}\right] \mathrm{N}$-methylscopolamine ( $\left.\left[{ }^{3} \mathrm{H}\right] \mathrm{NMS}\right)$, a radiolabeled ligand for muscarinic receptors, bound rapidly to pancreatic acini, and an equilibrium state of binding was observed within $60 \mathrm{~min}$ after the addition of this ligand (data not shown). This difference in binding characteristics between $\left[{ }^{3} \mathrm{H} \mid \mathrm{NMS}\right.$ and $\left[{ }^{3} \mathrm{H}\right] \mathrm{QNB}$ may be due to the hydrophobic property of the QNB molecule (28). Under the equilibrium condition, the specific binding of $\left[{ }^{3} \mathrm{H}\right] \mathrm{QNB}$ followed a simple isotherm saturation, and the Scatchard plot was linear. The values of $K_{d}$ and $B_{\max }$ for $\left[{ }^{3} H\right]$ QNB binding to pancreatic acini obtained in this study agreed well with those found in previous reports $(29,30)$. The linearity of the Scatchard plot of $\left[{ }^{3} \mathrm{H}\right] \mathrm{QNB}$ binding to isolated pancreatic acini is considered to be evidence for the presence of a single class of binding sites. Recently, the conccpt of subtypes of muscarinic receptors has becn proposed. In fact, the presence of subtypes in muscarinic receptors $\left(M_{1}\right.$ and $\mathrm{M}_{2}$ ) has been detected using new muscarinic antagonists $(31-33)$. The pancreatic acini was also found to have a low affinity for pirenzepine (PZ), an antagonist for the $M_{1}$ receptor, which suggests the presence of other subclasses of muscarinic receptors on pancreatic acini $(34,35)$. In recent studies, $P Z, a M_{1}$ antagonist, and AF-DX 116, a $\mathrm{M}_{2}$ antagonist, have been developed to analyze the subclass of muscarinic receptor involved in pancreatic enzyme release $(36,37)$. In the present study, the order of $\mathrm{IC}_{50}$ values of these muscarinic antagonists for $\left[{ }^{3} \mathrm{H}\right] \mathrm{QNB}$ binding and carbachol-stimulated amylase release was found to be as follows: atropine $<\mathrm{PZ}<\mathrm{AF}$ DX 116; These results are in good agreement with the data previously reported $(35,37)$. Although pancreatic acini showed a low affinity to pirenzepine, which suggested the presence of $M_{2}$ receptors, AF-DX 116 showed a less significant inhibitory effect on carbacholstimulated amylase secretion than pirenzepine. This may be due to the high cardio-selectivity of AF-DX $116(36,37)$.

Pancreatic acinar cells have capacities to secrete digestive enzymes such as amylase, chymotrypsinogen and lipase in response to muscarinic and CCK receptor activation. It is noteworthy that pancreatic acini prepared by collagenase treatment exhibited the secretory responses of these enzymes to muscarinic and CCK receptor agonists. Therefore, it is concluded that the isolated pancreatic acini used in this study have exocrine functions similar to pancreatic acinar cells in vivo. These results also suggest that isolated pancreatic acini may be useful for analyzing the mechanism of pancreatic exocrine secretion coupled with muscarinic and CCK receptors.

\section{REFERENCES}

1 Harper, A.A. and Scratchered, A.K.: Physiology. In The Exocrine Pancreas, Edited by Howat, H.T. and Sarles, H., p. 50-85, W.B. Saunders Co. Ltd., London (1979)

2 Gardner, J.D. and Jackson, M.J.: Regulation of amylase release from dispersed pancreatic acinar cells. J. Physiol. (Lond.) 270, $439-454$ (1977)

3 Gardner, J.D. and Jensen, R.T.: Regulation of exocrine secretion in vitro: the action of secretagogues. Philos. Trans. R. Soc. Lond. [Biol.] 296, $17-26$ (1981)

4 Amsterdam, A. and Jamieson, J.D.: Studies on dispersed pancreatic exocrine cells. 1. Dissociation technique and morphologic characteristics of separated cells. J. Cell Biol. 63, 1037-1056 (1974)

5 Amsterdam, A. and Jamieson, J.D.: Studies on dispersed pancreatic exocrine cells. 2. Functional characteristics of separated cells. J. Cell Biol. 63, $1057-1073$ (1974)

6 Williams, J.A., Korc, M. and Dormer, R.L.: Action of secretagogues on a new preparation of functionally intact, isolated pancreatic acini. Am. 
J. Physiol. 235, E517-E524 (1978)

7 Bommelaer, G., Rozental, G.. Bernier, C., Vaysse, N. and Ribet, A.: Action of secretagogues on amylase release from dog pancreatic acini. Digestion 21, 248-254 (1981)

8 Jensen. R.T. and Gardner, J.D.: Receptors for secretagogues on pancreatic acinar cells. J. Ped. Gastr. Nutr. 3, Supp. 1, S25-S35 (1984)

9 Kimura, T., Imamura, K., Eckhardt, L. and Schulz, I.: $\mathrm{Ca}^{2+}-$, phorbol ester-, and cAMP. stimulated enzyme secretion from permeabilized rat pancreatic acini. Am. J. Physiol. 250, G698G708 (1986)

10 Dagorn, J.C. and Estival, A.: Non-parallel enzyme secretion from rat pancreas in vitro studies. J. Physiol. (Lond.) 290, $51-58$ (1979)

11 Dubick, M.A., Majumdar, A.P.N., Kaysen. G.A. Burbige, E.J. and Geokas, M.C.: Secretagogue-induced enzyme release from the exocrine pancreas of rats following adaptation to a high protein diet. J. Nutr. 118, 305-310 (1988)

12 Duan, R.D. and Erlanson-Albertsson, C.: Effect of bile salt on amylase release from rat pancreatic acini. Scand. J. Gastroenterol. 20, 1239-1245 (1985)

13 Wroblewski, F. and LaDue, J.S.: Dehydrogenase activities in blood. Proc. Soc. Exp. Biol. Med. 90, $210-213(1955)$

14 Ceska, M. Birath, K. and Brown, B.: A new rapid method for the clinical detcrmination of $\alpha$ amylase activities in human serum and urine. Optimal conditions. Clin. Chim. Acta 26, 437-444 (1969)

15 Dagorn, J.C., Paradis, D. and Morisset, J.: Non parallel response of amylase and chymotrypsin biosynthesis following pancreatic stimulation: a possible explanation for observed non parallelism in pancreatic secretion. Digestion 15, 110-120 (1977)

16 Imondi, A.R., Stadley, R.P., Butler, E.R. and Wolgemuth, R.L.: A method of the assay of chymotrypsin in crude biological matcrials. Anal. Biochem. 54, $199-204$ (1973)

17 Kurooka, S., Okamoto, S. and Hashimoto, M: A novel and simple colorimetric assay for human serum lipase. J. Biochem. 81, 361 - 363 (1977)

18 Lowry, O.H., Roscbrough, N.J., Farr, A.L. and Randall, R.J.: Protein measurement with the Folin phenol reagent. J. Biol. Chem. 193, 265-275 (1951)

19 Larose, L., Dumont, Y., Asselin, J., Morisset, J. and Poirier, G.G.: Muscarinic receptor of rat pancreatic acini: $\left[{ }^{3} \mathrm{H}\right] \mathrm{QNB}$ binding and amylase secretion. Eur. J. Pharmacol. 76, 247-254 (1981)
20 Hootman, S.R. and Picado-Leanard, T.M.: Effect of proteolytic cleavage on functional propertics of muscarinic acetylcholine receptors in rat pancreatic and parotid acinar cells. Biochem. J. 231, 617-622 (1985)

21 Oliver, C.: Isolation and maintenance of differentiated exocrine gland acinar cells in vitro. In Vitro 16, 297-305 (1980)

22 Munger, B.L.: The ultra structure of the exocrine pancreas. In The Pancreas, Edited by Carey, L.C., p. 17 -31, The C.V. Mosby Co., St. Louis (1973)

23 Peikin, S.R., Rottman, A.J., Batzri, S. and Gardner, J.D.: Kinetics of amylase release by dispersed acini prepared from guinea pig pancreas. Am. J. Physiol. 235, E743-E749 (1978)

24 Williams, J.A.: An in vitro evaluation of possible cholinergic and adrenergic receptors affecting pancreatic amylase release. Proc. Soc. Exp. Biol. Med. 150, 513-516 (1975)

25 Barlas, N., Jensen, R.T, and Gardner, J.D.: Cholecystokinin-induced restricted stimulation of pancreatic enzyme secretion. Am. J. Physiol. 242, G464-G469 (1982).

26 Scheele, G.A. and Palade, G.E.: Studies on the guinea pig pancreas. Parallel discharge of exocrine enzyme activities. J. Biol. Chem. 250, 2660-2670 (1975)

27 Lahaie, R.G., Michel, R., Michel, G. and Dagorn, J.C.: Nonparallel secretion of enzymes by the rabbit pancreas. Can. J. Physiol. Pharmacol. 64, 297-302 (1985)

28 Aronstam, R.S., Abood, L.G. and Baumgold, J.: Role of phospholipids in muscarinic binding by neural membranes. Biochem. Pharmacol, 26, $1689-1695$ (1977)

29 Louie, D.S. and Owyang, C.: Muscarinic receptor subtypes on rat pancreatic acini: secretion and binding studies. Am. J. Physiol. 251, G275-G279 (1986)

30) Larose, L., Poirier, G.G., Dumont, Y., Fregeau, C., Blanchard, L. and Morisset, J.: Modulation of rat pancreatic amylase secretion and muscarinic receptor populations by chronic bethanechol treatment. Eur. J. Pharmacol. 95, 215-223 (1983)

31 Hammer, R., Berrie, C.P., Birdsall, N.J.M., Burgen, A.S.V. and Hulme, E.C.: Pirenzepine distinguishes between subclasses of muscarinic receptors. Nature 283, $90-92$ (1980)

32 Hammer, R. and Giachetti, A.: Muscarinic receptor subtypes: M1 and M2 biochemical and functional characterization. Life Sci. 31, 2991-2998 (1982)

33 Watson, M., Yamamura, H.I. and Roeske, W.R.: A unique regulatory profile and regional distribu- 
tion of $\left[{ }^{3} \mathrm{H}\right]$ pirenzepine binding in the rat provide evidence for distinct $\mathrm{M}_{1}$ and $\mathrm{M}_{2}$ muscarinic receptor subtypes. Life Sci. 32, 3001 - 3011 (1983)

34 Otuki, M., Nakamura, T., Okabayashi, Y., Oka, T., Fujii, M. and Baba, S.: Comparative inhibitory effect of pirenzepine and atropine on cholinergic stimulation of exocrine and endocrine rat pancreas. Gastroenterology 89, 408-414 (1985)

35 Jaworek, J. and Konturek, S.J.: Effects of pirenzepine and atropine on amylase response to various secretagogues from the rat pancreatic acini.
Digestion 36, $175-181$ (1987)

36 Hammer, R., Giraldo, E., Schiavi, G.B., Monferini, E. and Ladinsky, H.: Binding profile of a novel cardioselective muscarinic receptor antagonist, AF-DX 116, to membranes of peripheral tissues and brain in the rat. Life Sci. 38, 1653-1662 (1986)

37 Korc, M., Acherman, M.S. and Roeske, W.R.: A cholinergic antagonist identifies a subclass of muscarinic receptors in isolated rat pancreatic acini. J. Pharmacol. Exp. Ther. 240, 118-122 (1987) 